\title{
DOUBTING THE QURAN, THE HADITH, AND MUHAMMAD'S SPLITTING OF THE MOON: A PROBABILISTIC REFUTATION OF ONE OF ISLAM'S MOST STRIKING MIRACULOUS CLAIMS
}

\author{
RAPHAEL LATASTER *
}

University of Sydney

\begin{abstract}
Having spent many years engaging with Christian claims about miracles, especially the purported resurrection of Jesus, I now shift attention to Islamic miracle claims, the most striking of which seems to me to be Muhammad's alleged splitting of the moon. I explain, in a Bayesian fashion, why this almost certainly did not happen.
\end{abstract}

KEY WORDS: Islam, Apologetics, Quran, Miracles, Muhammad's splitting of the moon

\section{Introduction}

There seems to be in the Islamic traditions less of a focus on miracles. Christians tend to greatly value the many miracles of Jesus, which include healings and exorcisms, particularly his resurrection, the greatest and most important miracle of all. Muslims do not have as many miracles to appeal to in the Quran (apart from the composition of the Quran itself), though there is one that is quite striking. Read literally, it appears that the Quran, along with the Hadith, claims that Muhammad invoked God's power to cleave the moon in two, in order to show that Muhammad's God was indeed God:

The Hour has come near, and the moon has split [in two]. And if they see a miracle, they turn away and say, 'Passing magic' (Quran 54:1-2).

This hadith has been transmitted on the authority of Abdullah b. Mas'ud (who said): We were along with Allah's Messenger (may peace be upon him) at Mina, that moon was split up into two. One of its parts was behind the mountain and the other one was on this side of the mountain. Allah's Messenger (may peace be upbn him) said to us: Bear witness to this (Sahih Muslim 39:6725).

* RAPHAEL LATASTER (PhD 2017, University of Sydney) is an associate lecturer in Religious Studies at the University of Sydney, Australia. 
Anas reported that the people of Mecca demanded from Allah's Messenger (may peace be upon him) that he should show them (some) signs (miracles) and he showed tlicin the splitting of the moon. This hadlth has been narrated on the authority of Anas through another chain of transmitters (Sahih Muslim 39:6728).

There are alternatives to the literal interpretation, even within Islamic traditions. For example, this could refer to a future event, or it could be understood metaphorically. It is also worth noting that there is a stream of Islamic thought that denies that Muhammad was a miracle worker (apart from his role in the composition of the Quran):

But they say, 'Why are not signs sent down to him from his Lord?' Say, 'The signs are only with Allah, and I am only a clear warner.' And is it not sufficient for them that We revealed to you the Book which is recited to them? Indeed in that is a mercy and reminder for a people who believe (Quran 29:50-51).

And nothing has prevented Us from sending signs except that the former peoples denied them. And We gave Thamud the she-camel as a visible sign, but they wronged her. And We send not the signs except as a warning (Quran 17:59).

Nevertheless, there are Muslims, even very educated ones, who literally believe this miraculous claim refers to an authentic historical event. I shall now explain why this purported historical event most probably did not occur.

\section{Miracles and History}

History is not the study of what happened. We do not know what happened in the past, just as there is very little we know now. History is concerned with what probably happened in the past (we could also mull over what possibly happened, but that would seem vacuous, especially in matters of religious evangelism and evaluation). We determine what is probable through reason and empiricism, through evidence. In other words, we are technically interested in epistemic probabilities, hence our Bayesian approach. To be concise (more thorough explanations of the use of Bayesian probability by historians are available in Tucker 2004 and Carrier 2012), we compare various hypotheses with the more relevant evidence (and how expected this evidence is on the various hypotheses, which results in likelihoods), and also with background evidence that may also be relevant to the overall analysis (prior probabilities). For example, I often make the claim to my students that I recently met up with my friend Renee. The more direct evidence is a cheeky selfie on my camera phone. The relevant background knowledge is that Renee and I are friends, and I am generally an honest and mentally healthy person. Students tend to accept that the hypothesis that I really did meet Renee is quite probable. Then I introduce aliens into the mix. 
I claim that I met aliens recently, was subject to anal probing, and so forth. I have a photograph of the aliens approaching me from behind. The photograph seems convincing, but some students already raise the probability that the photograph is a fake. Why? Because this claim is inherently implausible. The hypothesis that I did really meet with aliens suffers from a very low prior probability. The students realise that verified human-alien interactions are very rare. In fact, especially since the rise of camera and video technology, there is as yet no convincing evidence that humans and aliens have met, or even that aliens exist (given the vastness of the universe, it may, of course, be quite probable that aliens exist. However, we do not know it. Yet). A photograph was sufficient for my earlier claim, but quite casually dismissed on the latter claim. After all, as we generally accept intuitively, and as effectively explained by the likes of Bayes, Hume, Sagan, and Hitchens, 'extraordinary claims require extraordinary evidence'.

One of the major problems with historical claims of miracles is that history (as well as science, etc.) is concerned with what is most probable, while miracles, by definition, are very improbable. Even believers in miracles tend to understand this-after all, if miraculous events were everyday events, they would not have the power to convince people that God exists, that Jesus was special, that Muhammad really was a prophet, etc. And the difficulty is not just with miracles themselves, it is with specific kinds of miracles. For example, with the resurrection of Jesus, we might ask how many confirmed resurrections have occurred throughout history, compared with the total claims of resurrections. We ought to omit the case of Jesus if we are analysing his alleged resurrection, but even with his case included, we would have just zero to one confirmed resurrection. Out of thousands of resurrection claims. In other words, not only are miracles inherently improbable, and they are supposed to be, claims of such miracles also tend to be false or at least unknown as being true.

Back to Muhammad's moon-splitting then, before we even examine the more direct evidence, namely the claims made in the Quran and Hadith, is there anything inherently improbable about the moon being split by Muhammad? I won't mention all the catastrophic impacts of the planet that a destroyed moon would be responsible for, since we can presume the moon was quickly reassembled. However, just off the top of my head, I would note that Muhammad was a mere mortal, of the 7th century CE, and such an undertaking would take incredible power/technology. So it does not seem very likely. Muslims might of course claim that such an event is not so unlikely when Allah's power is involved, but there is no convincing evidence that Allah even exists, and at the very least, most of us would reject this crucial premise making it, and the overall argument, very controversial indeed. There is also 
the problem that NASA has weighed in on the issue, finding no evidence that the moon has ever been split and then subsequently reassembled:

[Questioner:] You've already answered this question in August 2009 but I'd like to go into more detail. This website: http://www.mastikorner.com/forum/islamicpicx/6843-miracle-prophet-muhammad-p-b-u-h.html claims that Allah split the Moon in two at the request of the Prophet Mohammed and that there is a split on the Moon documented by American scientists that goes right around it which is evidence of the miracle. Is there any truth to any of these claims?

[Brad Bailey, NLSI Staff Scientist:] My recommendation is to not believe everything you read on the internet. Peer-reviewed papers are the only scientifically valid sources of information out there. No current scientific evidence reports that the Moon was split into two (or more) parts and then reassembled at any point in the past (Bailey 2019).

So it does seem that if we were to accept this specific claim of the moon being split, we would need some pretty extraordinary evidence. But all we are given is the Quran and the Hadith; Muslim sources. Oh dear.

\section{The Islamic Sources}

Our main source is the Quran. Can the Quran simply be trusted as a source of accurate historical information, or are there reasons to be doubtful (these considerations will go beyond merely declaring that certain parts of the Quran are ambiguous, non-literal, and so forth, which is always reasonable)? One of the first problems with the Quran, relative to chronology and importance, is the claim that the Quran is perfect, being the word of Allah, dictated to Muhammad via the angel Gabriel. This is already enough for most reasonable and objective scholars to dismiss the Quran and its miraculous claims. Does Allah exist? Does Gabriel exist? My own research into such questions reveals that scepticism here is more then fair (Lataster 2018), but even Muslim academics can accept that these premises are at the very least controversial. They would not even be accepted by most people who accept supernatural claims, such as Jews and Christians.

Now we turn to the Quran's supposed infallibility. There are, in fact, many errors therein, scientific and historic. One of the most jarring scientific errors is the apparent assumption of a flat Earth:

Until, when he reached the setting of the sun, he found it [as if] setting in a spring of dark mud, and he found near it a people... Until, when he came to the rising of the sun, he found it rising on a people for whom We had not made against it any shield (Quran 18:86-90). 
Of course, since we now know that the Earth is a sphere, it is an absurd notion to point to the locations where the Sun sets and rises. More errors:

Indeed, We have adorned the nearest heaven with an adornment of stars and as protection against every rebellious devil [so] they may not listen to the exalted assembly [of angels] and are pelted from every side, repelled; and for them is a constant punishment, except one who snatches [some words] by theft, but they are pursued by a burning flame, piercing [in brightness] (Quran 37:6-10).

And We have certainly beautified the nearest heaven with stars and have made [from] them what is thrown at the devils and have prepared for them the punishment of the Blaze (Quran 67:5).

It seems that the author of the Quran thinks that meteors are stars, and that they protect against the devils or demons, whoever and wherever they are, exactly. An example from another scientific field:

So let man observe from what he was created. He was created from a fluid, ejected, emerging from between the backbone and the ribs (Quran 86:5-7).

This may have seemed correct thousands of years ago, but contemporary people understand that the liquid in question, semen mixed with spermatozoa, is effectively produced in the seminal vesicles, prostate, bulbourethral glands, and testes. Turning to physics, an example which needs no commentary:

Do they not see the birds controlled in the atmosphere of the sky? None holds them up except Allah. Indeed in that are signs for a people who believe (Quran 16:79).

As for historical errors, one striking example:

And Solomon inherited David. He said, 'O people, we have been taught the language of birds, and we have been given from all things. Indeed, this is evident bounty.' And gathered for Solomon were his soldiers of the jinn and men and birds, and they were [marching] in rows. Until, when they came upon the valley of the ants, an ant said, 'O ants, enter your dwellings that you not be crushed by Solomon and his soldiers while they perceive not' (Quran 27:16-18).

Needless to say, no credible historian records that a Jewish king names Solomon commanded an army of birds, as well as demons. Such a tale is also not found in the Bible (though extra-biblical Jewish mythology is another matter). And no credible historian has ever confirmed that Solomon or anyone else can speak with ants. Moving on: 
The Jews say, 'Ezra is the son of Allah'; and the Christians say, 'The Messiah is the son of Allah.' That is their statement from their mouths; they imitate the saying of those who disbelieved [before them]. May Allah destroy them; how are they deluded? (Quran 9:30).

There is no earlier record of Jews proclaiming Ezra to be the son of God, and certainly not in the same way that Christians viewed Jesus' relationship with God the Father. Having said that, an example quite pertinent to Christians has the Quran indicating that Christians worship Mary as part of the triune God:

And [beware the Day] when Allah will say, 'O Jesus, Son of Mary, did you say to the people, "Take me and my mother as deities besides Allah?"' He will say, 'Exalted are You! It was not for me to say that to which I have no right. If I had said it, You would have known it. You know what is within myself, and I do not know what is within Yourself. Indeed, it is You who is Knower of the unseen' (Quran $5: 116)$.

Returning to the earlier claim, that 'the Quran is perfect, being the word of Allah, dictated to Muhammad via the angel Gabriel', we shall now consider if Muhammad did indeed author the Quran. While Muslims tend to think so, critical scholars of Islam are not so sure:

Qur'anic studies, as a field of academic research, appears today to be in a state of disarray. Those of us who study Islam's origins have to admit collectively that we simply do not know some very basic things about the Qur'an-things so basic that the knowledge of them is usually taken for granted by scholars dealing with other texts. They include such questions as: How did the Qur'an originate? Where did it come from, and when did it first appear? How was it first written? In what kind of language was-is-it written? What form did it first take? Who constituted its first audience? How was it transmitted from one generation to another, especially in its early years? When, how, and by whom was it codified? Those familiar with the Qur'an and the scholarship on it will know that to ask even one of these questions immediately plunges us into realms of grave uncertainty and has the potential to spark intense debate.

To put it another way, on these basic issues there is little consensus even among the well-trained scholars who work on them. I am not speaking here of the kind of routine difference of opinion or tension that exists in the study of all scriptural traditions between those who take that scripture as a source for their belief and life, and those who study it as a text on the basis of historical, literary, sociological, and theological analysis. Rather, I refer to the fact that so many scholars over the past century, despite deep learning, serious commitment to understand the Qur'an, and on the basis of sophisticated and subtle methods, nevertheless remain so lacking in consensus on these basic issues (Donner 2007: 29). 
Indeed, there have been scholars-going so far as to work under a pseudonym for personal security purposes-theorising that large portions of the Quran originate with earlier Christian and other sources (Luxenberg 2007). Furthermore, there has even been some effort to demonstrate that Muhammad may not have even existed (Spencer 2012). While I am generally open to doubt the existence of the founders of great religions, like Buddha or Jesus (Lataster 2019), I am more reluctant to do so for Muhammad, not for political or security reasons, but because he is only ever portrayed as a 'mere' prophet, a human being, with no actual supernatural attributes or powers. Nevertheless, it is at least a reasonable question to ask, and related questions about how much we can really know about Muhammad are even more worthwhile, due to several problems. For one, non-Islamic sources about Muhammad appear long after his death. The main sources are thus, as can be imagined, Islamic sources. Sources that would obviously be quite biased. Furthermore, apart from the Quran, which says relatively little about Muhammad, we have the Hadith and Sira, sources that arrive on the scene much later, and are supposedly derived from oral traditions, which are always problematic.

Given the undeniable bias of such sources, the errors therein, the outlandish claims made throughout, and the amount of fiction (even effectively admitted by Muslims who debate over which traditions are authentic) present, these are clearly not sources we can presume to be historically accurate. And that is before we begin to scrutinise manuscript dates (complete manuscripts of the Quran are found at least 100 years after the death of Muhammad), the integrity of transmission (even in Islamic tradition, Muhammad did not compile the Quran but had fragments written down and committed to memory by underlings, and after his death and the deaths of many of these 'scribes' Islamic leaders set about producing a single text, with Caliph Uthman destroying alternative readings in producing the Quran proper, all of which we can surely be at least a little suspicious about), textual variants, etc. Back to the miraculous splitting of the moon, we appealed not only to the Quran but to the Sahih Muslim collection of hadith. Though it is generally considered, by Muslims, to be among the most reliable of hadith collections, it was published centuries after the lifetime of Muhammad, and is of course a Muslim source. Thus, it (and the Hadith in general) is of little value to the critical scholar trying to ascertain whether the event in question had actually occurred in history.

It is very clear then that the more relevant evidence for the event is nowhere near enough to overturn the very low prior probability. This is an extraordinary claim, and it requires extraordinary evidence. The evidence available was not extraordinary, or even 'okay'; it was positively woeful. Hence, we can confidently assert that this miraculous event most probably did not happen. Please note that this is a Bayesian analysis, so additional 
evidence found in future could lead to a different result. It is unlikely that the prior probability will ever be increased, even for the simple fact that such claims are meant to be improbable. If they were common and probable events they would not have the power to convince people, like the Pagans of Mecca, about the power of Allah. The more direct evidence, however, the sources, could in principle be changed. While this also seems unlikely, I eagerly await further textual discoveries. Muslim apologists should not get their hopes up too much, however, as recent discoveries seem to only further undermine the confessional claims about Islamic origins and the Quran.

Perhaps the most important piece of evidence for this brief analysis is the lack of evidence. In a Bayesian analysis, the lack of evidence can certainly count as evidence when a hypothesis' being true creates expectations about extant evidence. And in this case, everybody else in the world happened to be ignorant of what would have been one of the most outstanding events in history. This lack of evidence, of course, is much more expected on alternative explanations, such as that the claim is simply fabricated in whole, or is a gross exaggeration of a much more benign event. Finally, it is worth a mention that there was a solar eclipse around the time, and likely viewable in Saudi Arabia, which increases the chances that something did occur, but subsequently further decreases the chances that that something was supernatural and involved the moon being literally split in two (NASA 2019).

\section{Conclusion}

Apart from the composition of the Quran itself, Islam tends to be lacking in grand miraculous claims, with few exceptions. One of the most important is the splitting of the moon by Muhammad, or actually by the power of Allah, as briefly described in the Quran. While some Muslims would opt for a nonliteral interpretation, many ancient and contemporary Muslims do accept the claim as a literal historical event, which is supported by the Hadith. However, arguing that this event did not occur is relatively straightforward, by simply reasoning in a Bayesian fashion.

Regarding prior probabilities, such claims are inherently very improbable. So far as we know, such events have never occurred. Furthermore, such claims are meant to be improbable, so as to have the power to convince observers that something very special, something divine, had just occurred. Paradoxically then, such claims ought to be accompanied by great evidence in order to convince rational critics; and so we move on to the likelihoods and the more direct evidence. The evidence comes from the Quran and the Hadith, sources that are highly questionable with regards to intent, authorship, integrity, historical accuracy, and more. Alternative explanations involving exaggerations and outright fabrication suit the poor standard of evidence 
much more. Appealing to Allah's existence would help some, though this is at best a very controversial premise.

As such, we can be very sure that the splitting of the moon by Muhammad or Allah very probably did not happen.

\section{Bibliography}

(Please note that for consistency, the years given for website sources are the access years, since many do not disclose the publication year.)

Bailey B (n.d.) https://lunarscience.nasa.gov/?question=evidence-moon-having-been-split-two, accessed 2019.

Carrier R (2012) Proving History: Bayes's Theorem and the Quest for the Historical Jesus. Amherst, NY: Prometheus Books.

Donner FM (2007) The Qur'an in Recent Scholarship: Challenges and Desiderata. In Reynolds GS (ed.) The Qur'an in its Historical Context. London: Routledge, pp. 29-50.

Lataster R (2018) The Case Against Theism: Why the Evidence Disproves God's Existence. Cham, Switzerland: Springer.

Lataster R (2019) Questioning the Historicity of Jesus: Why A Philosophical Analysis Elucidates the Historical Discourse. Leiden: Brill.

Luxenberg C (2007) The Syro-Aramaic Reading of the Koran: A Contribution to the Decoding of the Language of the Koran. Berlin: Schiller.

NASA (n.d.) https://eclipse.gsfc.nasa.gov/SEsearch/SEsearchmap.php? Ecl=06130-723, accessed 2019.

Spencer R (2012) Did Muhammad Exist? An Inquiry into Islam's Obscure Origins. Wilmington, DE: ISI Books.

Tucker A (2004) Our Knowledge of the Past: A Philosophy of Historiography. Cambridge: Cambridge University Press. 